\title{
ANALISIS SPASIAL KERENTANAN BENCANA GEMPA BUMI SESAR LEMBANG TERHADAP FASILITAS PENDIDIKAN DI KAWASAN BANDUNG RAYA
}

\author{
Spatial Analysis of The Vulnerability of Earthquake Caused by Lembang Fault on \\ Educational Facilities in Greater Bandung Area
}

\author{
Fajar Setia Pratama \\ SMA Negeri 1 Ngamprah \\ J1. Kenanga Raya PCI 2 Rt.01 Rw.19 Desa Tani Mulya Ngamprah, \\ Tanimulya, Kec. Ngamprah, Kab. Bandung Barat \\ E-mail: pratamasetiade@gmail.com
}

\begin{abstract}
The Greater Bandung is a regionalisms in West Java Province, consisting of the Bandung City, Cimahi City, Bandung Regency, West Bandung Regency and part of Sumedang Regency (in 5 sub-district). The area is inhabited by more than 8 million people or 18\% of West Java Province population. It become the central of economic growth and governmental center West Java. Northern area of The Greater Bandung geologically located on an active fault called Lembang Fault, about 29 kilometers extending from the west in West Bandung Regency to east in Sumedang Regency. Therefore, the vulnerability zoning needs to be done to reduce the impact of the disaster, including on education facilities. The zone is determined using spatial analysis done by weighing and calculating the disaster risk and overlaying the spatial data to create the disaster vulnerability zone map.. The map then be overlaid with the data points of education facilities to know which ones should have better preparation on earthquake hazard mitigation. The result showed about 139 educational facilities located in the radius of $5 \mathrm{~km}$ from Lembang Fault are having medium risk, while 77 education facilities located $10 \mathrm{~km}$ from Lembang Fault are facing higher level of risk
\end{abstract}

Keywords: Lembang Fault, Earthquake, Vulnerability Maps, The Greater Bandung, Education Facilities

Abstrak
Bandung Raya merupakan sebuah regionalisasi kawasan di Provinsi Jawa Barat, terdiri dari wilayah pemerintahan Kota Bandung, Kota Cimahi, Kabupaten Bandung, Kabupaten Bandung Barat dan sebagian Kabupaten Subang (5 kecamatan). Kawasan ini dihuni lebih dari 8 juta penduduk atau $18 \%$ dari total penduduk Provinsi Jawa Barat. Kawasan ini juga menjadi salah satu pusat pertumbuhan ekonomi dan pusat pemerintahan Provinsi Jawa Barat. Wilayah utara kawasan Bandung Raya secara geologis merupakan bagian wilayah aktif sesar Lembang. Memiliki panjang sekitar 29 kilometer, membentang dari wilayah barat di Padalarang hingga ke Tanjungsari. Oleh karenanya, penentuan zonasi kerentanan bencana perlu dilakukan untuk dapat mengurangi dampak dari bencana tersebut, khususnya terhadap fasilitas pendidikan. Penentuan zonasi menggunakan analisis spasial dilakukan dengan melakukan pemberian bobot prioritas perhitungan risiko bencana serta analisis overlay data spasial, sehingga akan didapatkan peta wilayah kerentanan bencana. Peta tersebut akan di overlay dengan data titik lokasi fasilitas pendidikan, sehingga diketahui fasilitias pendidikan mana saja yang harus dilakukan persiapan yang lebih dalam menghadapi potensi bencana gempa bumi. Hasil analisis menunjukan sekitar 139 fasilitas pendidikan yang berada di zona $5 \mathrm{~km}$ dari Sesar Lembang memiliki tingkat risiko sedang, dan 677 fasilitas pendidikan dalam zona $10 \mathrm{~km}$ dari sesar lembang memiliki tingkat risiko tinggi. 
Kata Kunci: Sesar Lembang, Gempa Bumi, Pemetaan risiko, Bandung Raya, Fasilitas Pendidikan.

\section{PENDAHULUAN}

Kawasan Bandung Raya atau Cekungan Bandung merupakan kawasan strategis nasional yang terdiri dari kawasan perkotaan yang membentuk kawasan metropolitan. Kawasan perkotaan ini terdiri dari kawasan perkotaan inti meliputi Kota Bandung dan Kota Cimahi dan kawasan perkotaan sekitarnya, seperti Kabupaten Bandung Barat, Kabupaten Bandung dan sebagian wilayah Kabupaten Sumedang yang mencakup Kecamatan Jatinangor, Cimanggung, Sukasari, Tanjungsari dan Pamulihan. Berdasarkan data BPS Provinsi Jawa Barat, Kawasan Bandung Raya memiliki jumlah penduduk 8.744.107 jiwa, atau sekitar $17,7 \%$ dari total penduduk Jawa Barat (BPS,2010).

Bentang alam wilayah Bandung Raya berada pada cekungan yang memiliki luas 343.087 hektar terdiri dari dataran dan pegunungan, dengan ketinggian 650-700 mdpl. Dikelilingi oleh beberapa gunung seperti; Gunung Tangkuban Perahu, Manglayang, Malabar, dsb. Karakteristik bentang alam tersebut menjadikan kawasan Bandung Raya memiliki banyak potensi alam yang dapat dikembangkan untuk menunjang kehidupan penduduk sekitarnya. Kawasan ini juga memiliki potensi bencana gempa bumi yang disebabkan oleh aktivitas sesar/patahan Sesar Lembang. Pergeseran sesar masih tergolong kecil dengan perubahan laju rata-rata 0,3 sampai $1,4 \mathrm{~cm} /$ tahun, jika di bandungkan dengan pergeseran lempeng besar Indo-Australia terhadap Lempeng Eurasia di sekitar Pulau Jawa yang memiliki pergerakan 6-7 cm per tahun. Seser Lembang memanjang sejauh 22-29 km, berpotensi gempa hingga mencapai 6,9 skala richter dengan magnitudo gempa sesar lembang 6,4-7 Mw (Purnama, 2018)

Penelitan untuk mengetahui keaktifan sesar lembang sebelumnya telah dilakukan oleh peneliti dari geodesi ITB, yang menyimpulkan bahwa adanya aktivitas gempa bumi pada tanggal 22 Juli dan 28 Agustus 2011 (Rasmid, 2014). Berdasarkan hasil kajian Badan Nasional Penanggulangan Bencana (BNPB) dalam rencana penanggulangan bencana 2015-2019, Jawa Barat ada dalam kawasan prioritas nasional untuk bencana gerakan tanah dengan kemungkinan yang terpapar lebih dari 33 juta jiwa. Kepadatan penduduk yang tinggi berbanding lurus dengan fasilitas infrastruktur untuk mendukung kehidupan sosial ekonomi yang akan berdampak pada kualitas sumberdaya manusia.

Pendidikan merupakan salah satu parameter dalam mengukur indeks pembangunan manusia. Fasilitas pendidikan wajib diberikan oleh pemerintah untuk memenuhi kebutuhan masyarakat dalam mengakses pendidikan. Undang-Undang Tahun 2003 Nomor 20 mengenai Sistem Pendidikan Nasional menyatakan bahwa pemerintah harus mampu menjamin peerataan kesempatan pendidikan, peningkatan mutu serta relevansi dan efesiensi manajemen pendidikan untuk tantangan sesuai dengan tuntutan perubahan lokal, nasional dan global (Gewab et al., 2015). Permasalahan yang sedang dihadapi masih kurangnya pengetahuan masyarakat tentang keberadaan Sesar Lembang, 
terutama di sektor pendidikan, jika terjadi bencana semua aspek kehidupan akan terkena dampaknya, tidak terkecuali fasilitas pendidikan.

Perlu diketahui wilayah mana saja yang harus waspada terhadap potensi gempa bumi Sesar Lembang. Perlunya peta potensi terdampak gempa Sesar Lembang yang disandingkan dengan sebaran fasilitas pendidikan, maka dapat ditampilkan berapa jumlah fasilitas pendidikan yang akan terkena dampak langsung oleh aktivitas Sesar Lembang sehingga dapat dilakukan kegiatan pencegahan dan penyuluhan sebelum terjadinya bencana gempa bumi.

Proses pengumpulan data dilakukan dengan mengumpulkan data sekunder dari instansi atau dinas-dinas terkait. Studi kepustakaan dilakukan dengan meninjau sumber yang berkaitan dengan tema penelitian ini, berupa buku, hasil penelitian terdahulu, data digital pemetaan. Metode Analisis Untuk menentukan zona kerentanan gempabumi diperlukan beberapa tahapan analisis, yang pertama adalah analisis penentuan zona kerentanan bencana gempa bumi sesar lembang menggunakan teknik analisis overlay, Singkatnya, analisis overlay yaitu menganalisis suatu peta digital pada peta digital yang lain beserta atribut-atributnya dan menghasilkan peta gabungan keduanya yang memiliki informasi atribut dari kedua peta tersebut dari beberapa peta yang berkaitan variabel yang digunakan yaitu kerentanan fisik, sosial dan ekonomi dengan pemobotan. Selanjutnya, analisis perhitungan fasilitas pendidikan yang rusak akibat dari potensi gempa sesar lembang, dengan overlay titik fasilitas pendidikan dengan zonasi kerentanan bencana. Materi teknis yang berkaitan dengan Sesar Lembang yang digunakan pada penelitian ini didapatkan dari berbagai sumber dan tidak dilakukan penelitian lapangan terhadapnya.

\section{PEMBAHASAN}

\section{Kawasan Bandung Raya}

Kawasan Bandung Raya atau Kawasan Perkotaan Cekungan Bandung merupakan kawasan strategis nasioal dari sudut pandang kepentingan ekonomi yang terdiri dari kawasan perkotaan inti dan kawasan perkotaan di sekitarnya yang membentuk kawasan metropolitan. Kawasan perkotaan inti yang dimaksud yakni Kota Bandung dan Kota Cimahi, Kawasan perkotaan sekitarnya di antaranya wilayah Kabupaten Bandung Barat, Kabupaten Bandung dan sebagian wilayah Kabupaten Sumedang, memiliki luas 3620,29 km persegi dengan jumlah penduduk 8.967.311 jiwa, Kota Bandung menjadi kota terpadat, Kota ini menjadi pusat ekonomi dan pemerintahan Provinsi Jawa Barat.

Wilayah utara berbatasan langsung dengan wilayah Kabupaten Subang, bagian barat berbatasan dengan Kabupaten Cianjur dan Kabupaten Purwakarta, di bagian timur dan selatan berbatasan dengan Kabupaten Garut. Bagian tengah dari Cekungan Bandung berupa dataran yang luas dengan pegunungan yang mengelilinginya dari berbagai arah. Penggunaan lahan di sekitar Bandung Raya digunakan sebagai perkebunan teh, sayuran, seperti wilayah Lembang, Parongpong dan Cisarua serta Ciwidey, Pangalengan di wilayah selatan. Wilayah dataran Bandung Raya 
dikembangkan sebagai kawasan industri, pemukiman dan perkotaan, dan sebagain masih digunakan untuk lahan persawahan khususnya di wilayah Kabupaten Bandung dan sebagain wilayah Kota Bandung bagian tenggara.

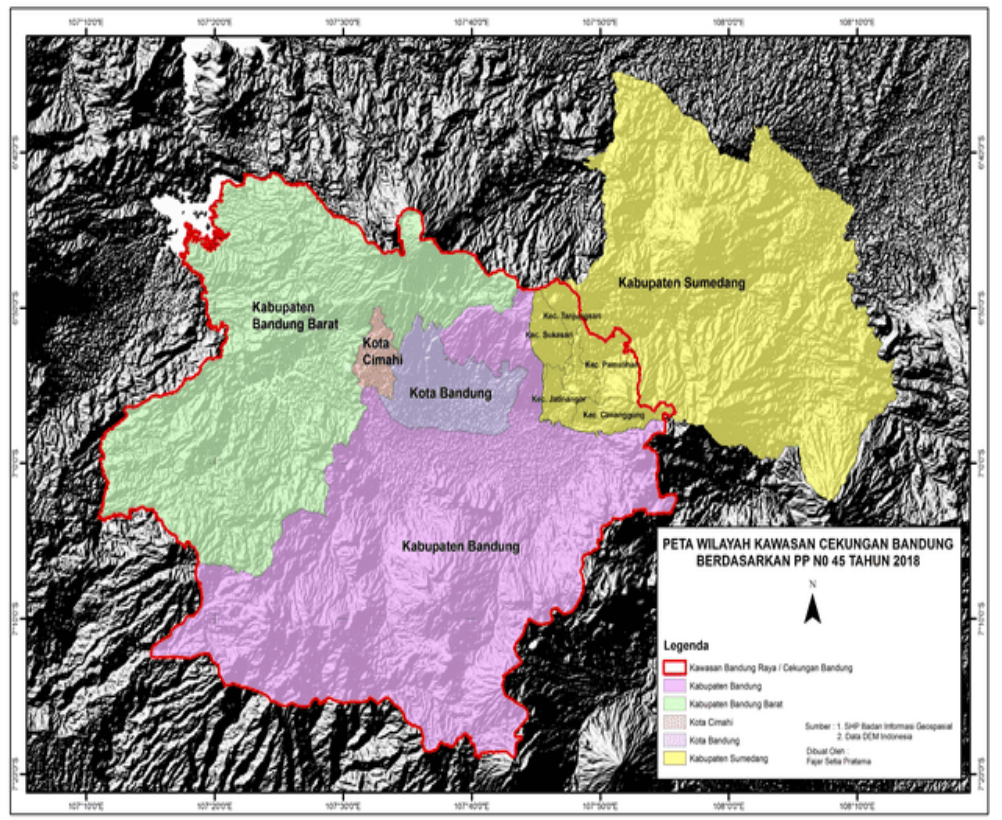

Gambar 1. Peta Kawasan Bandung Raya berdasarkan Perpres Nomor 45 tahun 2018. Sumber: File .shp BIG dengan pengolahan oleh penulis, 2020

\section{Sesar Lembang}

Sesar atau patahan Lembang memiliki panjang sekitar $29 \mathrm{~km}$, berada di utara Cekungan Bandung, membentang mulai dari kaki Gunung Manglayang hingga ke kawasan Padalarang di Kabupaten Bandung Barat. Tercatat pernah terjadi beberapa kali gempa bumi yang diakibatkan oleh Sesar Lembang, yaitu pada tahun 1834, 1879, 1910, 2003 dan 2011 berkekuatan 3 skala richter. Hasil studi ini menunjukan bahwa wilayah utara dari kawasan Cekungan Bandung memiliki potensi bahaya guncangan gempa (Yunarto, 2019)

Wilayah utara kawasan Bandung Raya saat ini telah menjadi salah satu destinasi wisata yang sangat digemari oleh masyarakat Bandung Raya maupun luar kota. Di sekitar Sesar Lembang kini banyak dibangun pemukiman dan fasilitas umum. Bangunan tersebut banyak dibangun di dasar patahan sisi utara dan di puncak patahan sisi selatan. Untuk memantau aktivitas Sesar Lembang pihak terkait telah memasang seismograf di puncak Gunung Batu, lokasi tersebut menjadi salah satu bentang alam akibat dari Sesar Lembang (Rismawati, 2019)

Berdasarkan Peraturan Daerah Provinsi Jawa Barat Nomor 22 Tahun 2010 tentang Rencana Tata Ruang Wilayah Provinsi Jawa Barat 2009-2029, Kabupaten Bandung dan Kabupaten Bandung Barat termasuk kawasan rawan bencana alam, terlebih di wilayah sekitar Sesar Lembang. Maraknya pembangunan serta besarnya jumlah penduduk yang bermukim di sekitar Sesar Lembang akan memberikan dampak 
bencana yang tidak sedikit. Adanya potensi bencana tersebut mengharuskan pemerintah sebagai pemangku kebijakan harus lebih ketat dalam pengawasan untuk pendirian izin pembangunan, semua pembangunan harus sesuai dengan dokumen hukum penataan ruang yang telah disusun sesuai dengan kondisi di sekitar Sesar Lembang.

\section{Bencana $=$ Bahaya $\mathbf{x}$ Kerentanan}

Terdapat persamaan bencana = bahaya $\mathrm{x}$ kerentanan. Persamaan tersebut secara umum memperlihatkan bahwa bencana terjadi karena adanya interaksi antara bahaya dan kerentaan (Bahri \& Madlazim, 2012). Di Indonesia kerentanan bencana ditentukan melalui beberapa aspek yaitu, lokasi komunitas dari pusat ancaman, tingkat kepadatan penduduk, kemiskinan, pendidikan, kesehatan, laju pertumbuhan ekonomi, pendapatan asli daerah, produk domestik regional bruto serta tenaga kerja. Kawasan Bandung Raya yang sudah berkembang menjadikan kawasan tersebut rentan terhadap bencana yang akan memberikan wilayah tersebut semakin berpotensi terdampak bencana yang lebih besar.
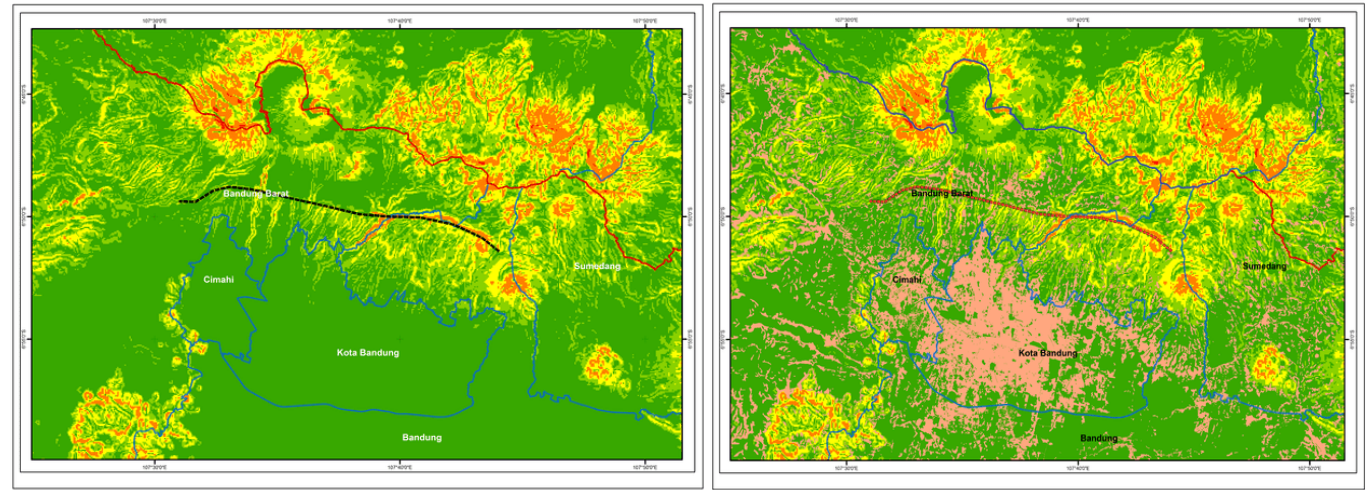

Gambar 2\&3. Peta Sesar Lembang (kiri) Sesar Lembang dan Pemukiman (kanan). Sumber : Shp BIG \& PVMBG diolah oleh penulis, 2020

Pada penelitian risiko bencana yang menghitung beberapa faktor yaitu, kerentanan fisik, sosial dan ekonomi kawasan Sesar Lembang memiliki 3 tingkatan risiko, risiko rendah, sedang dan tinggi. Dengan ketentuan radius 1-5 km untuk tingkat risiko tinggi, 6-10 km risiko sedang, serta lebih dari $10 \mathrm{~km}$ risiko rendah. Wilayah yang memiliki tingakatan risiko tinggi terjadi karena banyaknya pemukiman atau tempat wisata yang akan berpotensi terkena dampak aktivitas Sesar Lembang (Wardhiny, 2014). Berdasarkan hasil catatan gempa bumi yang pernah terjadi akibat Sesar Lembang, wilayah yang pernah mengalami gempa yaitu KecamatanLembang, Cisarua dan Tanjung Sari (Rasmid, 2014)

Diperlukan mitigasi yang baik di sekitar Sesar Lembang, di antaranya melakukan pemetaan detail pada Fault Rupture Hazard Zone (FRHZ) jalur dan sesar aktif, menghindari pembangunan di wilayah FRHZ jalur dan zona sesar aktif, memasang petunjuk pada jalur sesar aktif, menentukan jalur evakuasi yang aman bagi masyarakat apabila terjadi peningkatan aktivitas Sesar Lembang, melakukan penyuluhan kepada 
masyarakat yang tinggal di sekitar Sesar Lembang termasuk berlatih bagaimana cara untuk menyelamatkan diri saat terjadi bencana gempabumi (Dewi et al., 2014).

\section{Fasilitas Pendidikan}

Fasilitas Pendidikana merupakan aktivitas atau materi yang dapat melayani kebutuhan masyarakat akan kebutuhan yang bersifat memberi kepuasan sosial, mental dan spiritual melalui perwujudan suasana belajar dan proses pembelajaran yang menjadikan peserta didik secara aktif mengembangkan potensi dirinya. Sementara itu, pengertian pendidikan adalah usaha sadar setra terencana untuk mewujudkan suasana belajar dan proses pembelajaran sehingga peserta didik secara aktif mengembangkan potensi dirinya untuk menumbuhkan keagamaan, pengendalian diri, kepribadian, kecerdasan, ahlak mulia serta keteramilan yang diperlukan dalam kehidupan bermasyarakat. Terdapat 4 jenis fasilitas pendidikan menurut Kementrian PU No.378/KPTS/87 yaitu TK (merupakan fasilitas pendidikan dasar yang diperuntukan untuk anak usia 5-6), SD (fasilitas pendidikan untuk anak usia 6-12 tahun), SMP (sarana untuk melayani fasilitas lulusan SD), dan SMA (sarana untuk melayani fasilitas lulusan SMP). Setiap fasilitas dalam satuan pendidikan meliputi lahan, bangunan gedung, dan aspek lain yang dapat mendukung proses belajar mengajar (Gewab et al., 2015)

Kawasan Bandung Raya memiliki 11.544 fasilitas pendidikan, pada (Tabel 1) dan (Gambar 4) berikut adalah data sebaran lokasi fasilitas pendidikan di kawasan Bandung Raya;

\begin{tabular}{|l|c|c|c|c|}
\hline \multicolumn{1}{|c|}{ Satuan Pendidikan } & \multirow{2}{*}{ TK } & SD & SMP & SMA/SMK \\
\cline { 1 - 6 } \multicolumn{1}{|c|}{ Wilayah } & 1393 & 544 & 298 & 179 \\
\hline Kota Bandung & 400 & 138 & 61 & 49 \\
\hline Kota Cimahi & 1410 & 915 & 324 & 140 \\
\hline Kab. Bandung Barat & 2658 & 1635 & 568 & 232 \\
\hline Kab. Bandung & 335 & 144 & 72 & 49 \\
\hline Kab. Sumedang (5 Kecamatan) & 6196 & 3376 & 1323 & 649 \\
\hline Jumlah & & \\
\hline
\end{tabular}

Tabel 1. Tabel Jumlah Fasilitas Pendidikan di Bandung Raya (kiri)

Gambar 2. Peta Sebaran Fasilitas Pendidikan (kanan)

Sumber: File .shp BIG dan data Kemendikbud RI dengan pengolahan oleh penulis, 2020

\section{Sesar Lembang dan Fasilitas Pendidikan}

Untuk mengetahui fasilitas pendidikan mana saja yang berisiko terkena dampak dari Sesar Lembang, dilakukan overlay antara sebaran titik fasilitas pendidikan dengan Kawasan Sesar Lembang. Sebaran titik fasilitas pendidikan diperoleh dari INA Geo Portal Badan Informasi Geospasial dan data dari Kementrian Pendidikan yang diolah menggunakan perangkat lunak ArcGIS. Pertama, dilakukan pembuatan-zonasi dengan tool buffer zona $5 \mathrm{~km}$ untuk risiko sedang dan $10 \mathrm{~km}$ untuk risiko tinggi. Selanjutnya 
tool intersect untuk mengkasifikasikan dan mengetahui jumlah fasilitas pendidikan yang ada pada zonasi risiko sedang dan risiko tinggi.

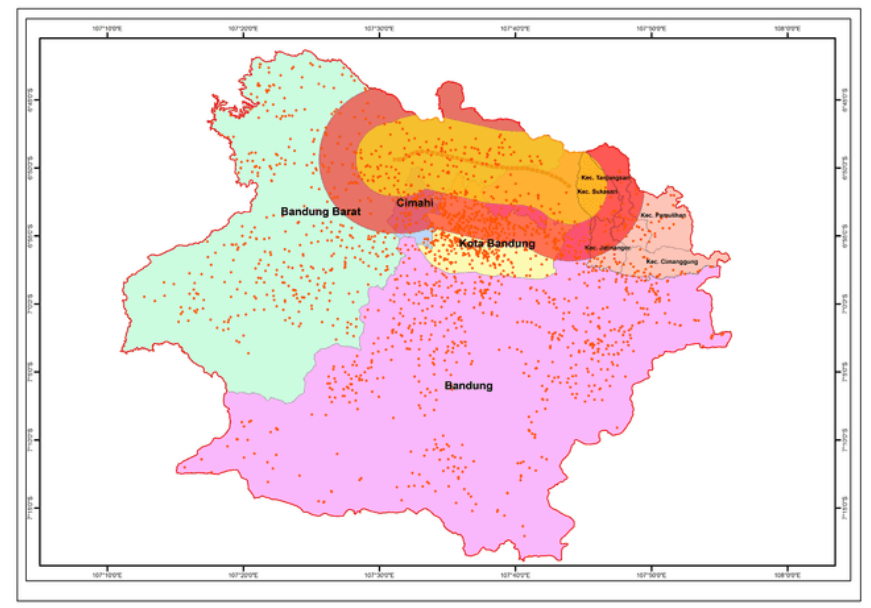

Gambar 5. Peta buffering risiko bencana terhadp fasilitas pendidikan Sumber: File .shp BIG dan data Kemendikbud RI dengan pengolahan oleh penulis, 2020

Berdasarkan hasil analisis spasial, terdapat 139 fasilitas pendidikan dalam radius $5 \mathrm{~km}$ dari Sesar Lembang dengan tingkat risiko sangat tinggi, meliputi wilayah Kecamatan Lembang, Cisarua, Parompong di Kabupaten Bandung Barat, dengan 98 fasilitas pendidikan, 5 fasilitas pendidikan di Kecamatan Cimahi Utara Kota Cimahi, 17 fasilitas di Kota Bandung, dan 19 fasilitas di Kabupaten Bandung. Angka lebih besar ditunjukan pada zona $10 \mathrm{~km}$ dari Sesar Lembang, sebanyak 677 fasilitas, wilayah yang kemungkinan berisiko tinggi meliputi Kota Cimahi, Kota Bandung bagian utara, Kabupaten Bandung Barat bagian timur laut, Kabupaten Bandung pada bagian utara di Kecamatan Cimenyan dan Cilengkrang serta Kecamatan Tanjungsari dan Sukasari di Kabupaten Sumedang.

Kawasan yang berada di luar dari zonasi $10 \mathrm{~km}$ memiliki tingkat risiko yang rendah. Berdasarkan hasil dari pemetaan diatas akan ada lebih dari 600 fasilitas pendidikan yang akan terkena dampak dari aktivitas Sesar Lembang, perlu adanya edukasi atau penyuluhan kepada satuan pendidikan akan bahaya dari Sesar Lembang untuk menekan kerugian dan korban jiwa bila ada gempa terjadi. Hal yang bisa dilakukan seperti membuat jalur evakuasi di satuan pendidikan masing-masing, serta melakukan latihan bila menghadapi gempa bumi. Pemerintah atau pemangku kebijakan juga dapat mempertimbangkan untuk membangun fasilitas pendidikan/sekolah yang berada di wilayah zona risiko, dengan kualitas bangunan tahan gempa, sehingga menurunkan dampak kerugian dari bencana gempa bumi yang akan timbul dimasa depan. 


\section{SIMPULAN}

Berdasarkan hasil analisis spasial sebaran fasilitas pendidikan terhadap Sesar Lembang, terdapat 3 zona yaitu zona bahaya dengan radius 250, zona risiko tinggi yang berada di radius $1-5 \mathrm{~km}$, zona risiko menengah pada radius $5-10 \mathrm{~km}$, serta zona risiko rendah yang berada pada radius lebih dari $10 \mathrm{~km}$ dari Sesar Lembang. Penentuan zona ini dihitung berdasarkan pembobotan risiko bencana gempa bumi yang dilihat dari beberapa aspek. Fasilitas pendidikan yang terdampak mencapai lebih dari 600 fasilitas pendidikan yang terdiri dari TK-SMA. Diharapkan satuan pendidikan yang ada di sekitar zona risiko dapat tanggap dengan potensi bencana gempa bumi yang diakibatkan oleh Sesar Lembang dimasa yang akan datang.

\section{DAFTAR PUSTAKA}

Bahri, S., \& Madlazim, M. (2012). Pemetaan Topografi, Geofisika Dan Geologi Kota Surabaya. Jurnal Penelitian Fisika Dan Aplikasinya (JPFA), 2(2), 23. https://doi.org/10.26740/jpfa.v2n2.p23-28

Dewi, A. K., Hamzah, A., Pramatadie, A. M., Prajanto, B., \& Meilano, I. (2014). Menghadapi Gempabumi.

Gewab, H. C., Malik, A. A., Karongkong, H. H., Program, M., Perencanaan, S., Arsitektur, J., Ratulangi, U. S., Pengajar, S., Arsitektur, J., Ratulangi, U. S., \& Saefulhakim, S. (2015). Analisis Kebutuhan Dan Sebaran Fasilitas Pendidikan Tingkat Smp Dan Sma Di Kabupaten Tambrauw, Propinsi Papua Barat. Spasial, 2(3), 43-52.

Purnama, A. R. (2018). Studi Sesar Lembang Menggunakan Citra Sentinel-1a Untuk Pemantauan Potensi Bencana Gempa Bumi. Jurnal Geodesi Undip, 7(4), 304-313.

Rasmid, R. (2014). Aktivitas Sesar Lembang Di Utara Cekungan Bandung. Jurnal Meteorologi Dan Geofisika, 15(2), 129-136. https://doi.org/10.31172/jmg.v15i2.182

Rismawati, R. (2019). Sesar Lembang: Potensi Bencana Di Kawasan Perkotaan Cekungan Bandung (Suatu Tinjauan Yuridis). Creative Research Journal, 5(01), 23. https://doi.org/10.34147/crj.v5i01.193

Wardhiny, B. K. (2014). Kajian Analisis risiko Bencana Sesar Dalam Penyusunan Arahan Pemanfaatan Ruang Berbasis Mitigasi Bencana Sesar (Studi Kasus Kecamatan Lembang). 97-100.

Yunarto, Y. S. (2019). Pemetaan Kesiapsiagaan Rumah Tangga Dalam Mengantisipasi Bencana Gempa Bumi Patahan Lembang. Jurnal Geografi, 11(1), 1-18. https://doi.org/10.24114/jg.v11i1.11328 


\section{HASIL DISKUSI}

\section{Pertanyaan}

1. Adi (Bandung Mitigasi Hub)

Apakah ada hubungan antara sesar lembang dengan sesar lainya di Jawa Barat?

2. Yuni

Dampak besar apa yang bias terjadi, dan apakah dapat membahayakan wilayah Kota Bandung?

\section{Jawaban}

1. Ada, seperti wilayah sesar di Tanjungsari, Sukabumi dan wilayah pesisir utara Jawa Barat, namun perlu dikaji lebih komprehensif lagi karena penulis belum menguasai secara detail dari sudut pandang geologisnya.

2. Dampaknya tentu saja ada, meski perlu dikaji lagi, apalagi mengingat wilayah KBU sudah banyak bangunan-bangunan hunian dan rekreasi, sehingga jika ada aktivitas kegempaan akan menimbulkan kerugian yang tidak sedikit. 